\title{
Moyamoya syndrome and neurofibromatosis type 1
}

\author{
Euthymia Vargiami', Evdoxia Sapountzi ${ }^{1}$, Dimitris Samakovitis ${ }^{1}$, Spyros Batzios ${ }^{1}$, Maria Kyriazi $^{1}$, \\ Athanasia Anastasiou ${ }^{2}$ and Dimitrios I Zafeiriou ${ }^{1 *}$
}

\begin{abstract}
Neurofibromatosis type 1 (NF1) is the most prevalent autosomal dominant genetic disorder among humans. NF1 vasculopathy is a significant but underrecognized complication of the disease, affecting both arterial and venous blood vessels of all sizes. Moyamoya syndrome is a cerebral vasculopathy that is only rarely observed in association with NF1, particularly in the pediatric age range. Herein, we report of a 5-year-old female with NF1 and moyamoya syndrome and we briefly review the existing literature.
\end{abstract}

Keywords: Moyamoya syndrome, Neurofibromatosis type 1 (NF1), Vasculopathy, Infarct, Central nervous system, Childhood

\section{Introduction}

Neurofibromatosis type 1 (NF1) or von Recklinghausen is the most common neurocutaneous contidion with an autosomal dominant pattern of inheritance. $1 / 3$ of cases are new mutations [1]. This genetic disorder caused by mutations of the NF1 gene which is located on chromosome 17(17q11.2) [1]. Patients with NF1 may present with a variety of central nervous system complaints, such as seizures, learning disability and attention-deficit disorder. Intracranial lesions associated with NF1 include optic gliomas, sphenoid wing dysplasia, "unidentified bright objects" (UBOs) [1,2]. Cerebrovascular lesions such as moyamoya syndrome are rarely seen in NF1 [2]. Herein, we report of a 5-year-old female with NF1 and moyamoya syndrome and we briefly review the existing literature.

\section{Case report}

A 5 year-old female was admitted to the hospital with a history of acute right-sided weakness. The physical examination revealed several café-au-lait spots (larger than $0.5 \mathrm{~cm}$ ) and freckling in the inguinal area and the axillae, thus fulfilling diagnostic criteria for NF1 [1,2]. The neurologic examination demonstrated right spastic hemiplegia with increased muscle tone of upper and low extremities, increased tendon reflexes as well as right facial nerve palsy.

\footnotetext{
* Correspondence: jeff@med.auth.gr

${ }^{1} 1$ st Department of Pediatrics, Aristotle University of Thessaloniki, Egnatia St. 106, Thessaloniki 54622, Greece

Full list of author information is available at the end of the article
}

Regarding the NF1 work-up, including laboratory investigations, complete blood cell count, blood biochemistry, radiographs of long bones, electroencephalogram, visual and brainstem auditory evoked potentials, echocardiography, abdominal ultrasound and ophthalmologic examination were normal. Brain magnetic resonance imaging (MRI) of the brain, showed multiple small foci of T2 prolongation in the right periventricular white matter, as well as both globus pallidi and cerebellar hemispheres ("unidentified bright objects" -UBOs). These lesions were hypointense on T1-weighted images, did not show any mass effect, and did not enhance after intravenous contrast injection (Figure 1). Also, multiple dot-like flow-void enhancing areas in basal gaglia and thalamus representing lenticulostriade collateral vessels were seen (Figure 2).

Magnetic resonance angiography of the brain (MRA) (and subsequent digital subtraction angiography), showed occlusion of the terminal left internal carotid artery (ICA) and severe stenosis of the proximal middle and anterior cerebral arteries, with multiple tiny basal collateral arteries (Figure 3). Anterior circulation was supplied mainly by these lenticulostriate and thalomo-perforator collaterals vessels. The right ICA and the posterior circulation were normal. These findings were considered as typical for moyamoya syndrome. Additional examinations included clotting, thrombophilia screen, iron and folate screen, demonstrated normal findings.

After neurosurgical consultation, surgical revascularisation [namely a left encephalo-duroarterio-synangiosis 

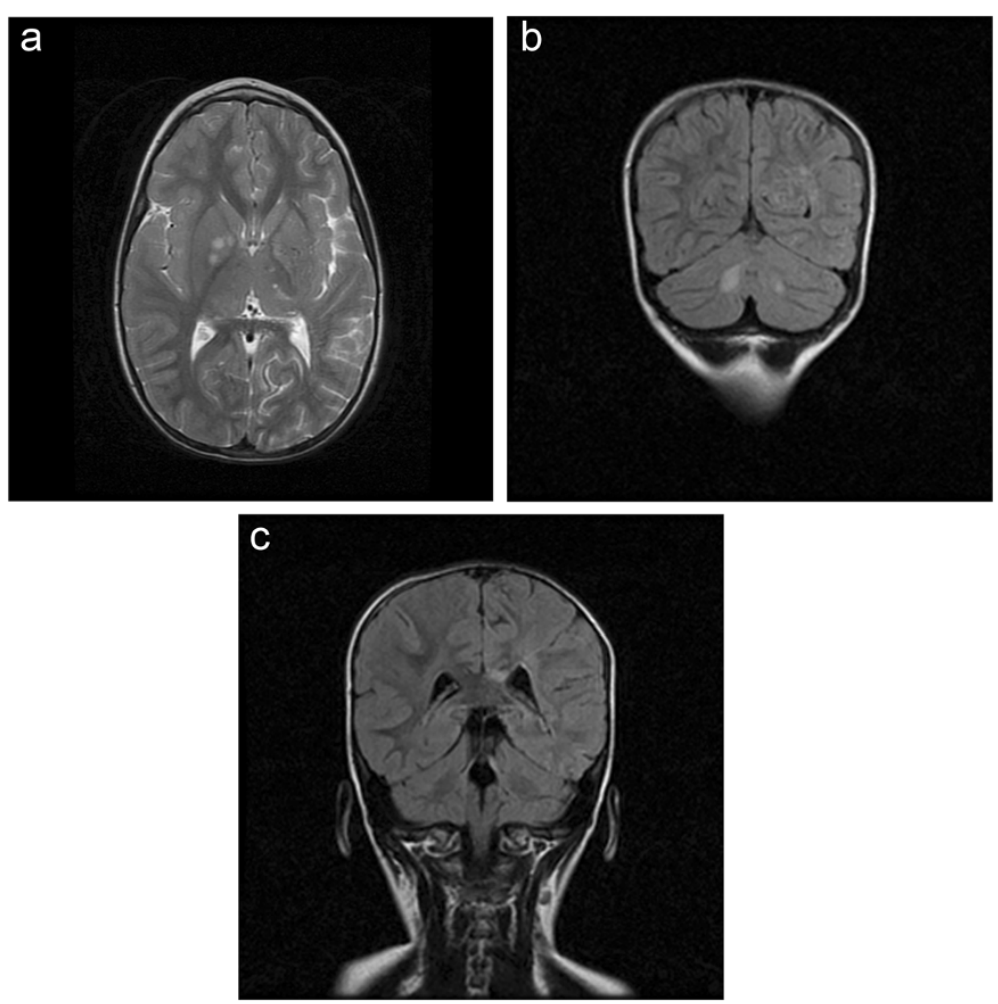

Figure 1 Brain MRI: T2-weighted images (TR/TE 4000/99) showed pathologic areas of increased signal, a. in right basal ganglia (UBO'S), b. lin the deep white matter of cerebellum, c. in corpus callosum demonstrated typical areas of UBO'S (unidentified bright objects) in NF 1 disease.

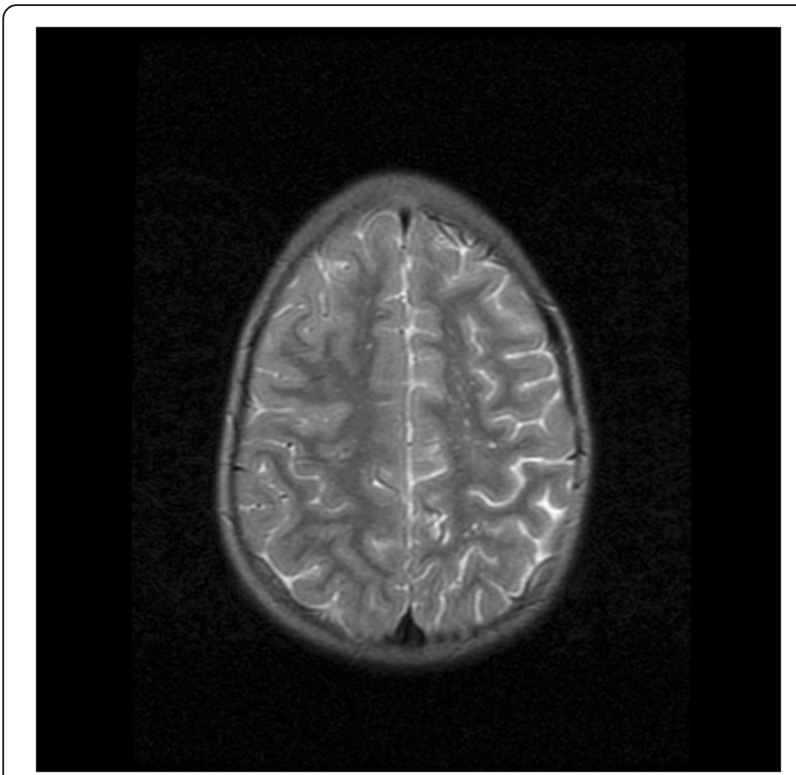

Figure 2 Brain MRI: T2-weighted images (TR/TE 4000/99) showed multiple sites empty signal mainly in the left basal ganglia and ipsilateral lunate center in as in the presence of collateral vessels.
(EDAS)], was carry out electively. The intraoperative and postoperative course was unremarkable. Treatment with aspirin was immediately started and physical and occupational therapy was initiated. At 2-years follow-up her facial weakness had resolved (since 6 months postoperative), but still demonstrates a mild right hemiparesis.

\section{Discussion}

NF1 is multisystemic disease, which affect the skin, central nervous system and bone system [1,2]. Its diagnosis is based on the clinical criteria established by the National Institutes of Health (NIH) Consensus Development Conference [3]. For a definitive diagnosis of NF-1, two or more of the following clinical characteristics must be present, six or more café-au-lait spots with a diameter more than $5 \mathrm{~mm}$, two or more neurofibromas, axillary or inguinal freckling, one reticular neurofibroma, two or more Lisch nodules (hamartomas), an optic glioma, skeletal abnormalities, such as sphenoid dysplasia or pseudarthrosis of the tibia and first degree relationship with a patient suffering from NF1 [3]. These criteria are not sensitive to very young children, since many of them may appear gradually over the years, while children over 10 years old who do not meet the criteria are unlikely to suffer from NF1 [3].

NF1 vasculopathy is a significant but under-recognized complication of the disease, affecting arterial and venous 


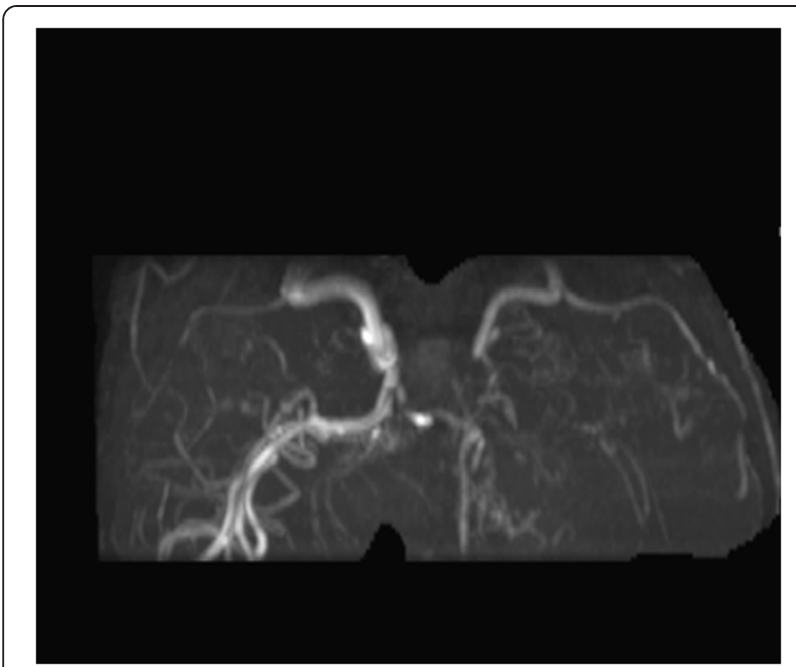

Figure 3 MR angiography of the brain (MRA): virgate imaging petrous segment and the proximal portion of the left internal carotid artery and occlusion of the distal vessel.

blood vessels of all sizes. Although the arterial system is most commonly affected, venous circulation may also be involved [2]. A variety of vascular lesions have been noted in patients with NF1, including occlusion, aneurysm, pseudoaneurysm, ectasia, stenosis, fistula and rupture $[4,5]$. According to bibliographic data, the internal carotid artery is most commonly affected, followed by middle and posterior cerebral artery. Although rare in childhood, there was extracranial vascular involvement mainly in the renal artery [5]. The main characteristic of vascular lesions in patients with NF-1 is occlusion of the lumen and hyperplasia of the intima wall. Based on microscopic evaluation of the affected vessels, it has been proposed that the vasculopathy of NF-1 patients results from abnormal neurofibromin function that leads to excessive proliferation of vascular smooth muscle cells during normal maintenance of the vessel. Conversely, even though neurofibromin is known to be expressed in vascular smooth muscle cells, little is known about its function relating to controlling endothelial cell proliferation $[2,5,6]$.

The precise mechanisms involved in NF1, the pathogenesis of vasculopathy are poorly understood but are likely related to the function of neurofibromin, the protein product of the NF1 gene [6]. Neurofibromin has been identified in the endothelial layer of bovine and rodent cerebral and renal arteries, as well as the aorta. It has been hypothesized that the loss of neurofibromin expression in endothelial cells may somehow cause vascular smooth muscle cells to proliferate [6]. It has also been suggested that neurofibromin helps maintain the integrity of the endothelial cell layer, and if this integrity is lost because of aberrant neurofibromin, vascular smooth muscle cells could proliferate $[2,6]$.

Moyamoya syndrome is a rare disorder developing by stenosis and occlusion of small anastomotic vessels in distal branches of bilateral internal carotid arteries $[7,8]$. Nonetheless, its etiology continues to be illdefined. Moyamoya syndrome is more frequently observed in the Japanese population, with an estimated incidence of one new case per 1,000,000 individuals per year [7]. The clinical findings present with neurological symptoms, whereas ischemic stroke develops in young adults, subarachnoid hemorrhage develops in older patients in moyamoya syndrome [7].

The prevalence of moyamoya syndrome in NF1 patients is estimated at $0.6 \%$, with more than one hundred cases reported in paediatric patients since 1976 (Table 1) [8-43]. Moyamoya syndrome in patients with NF1 is often initially unilateral and often involves anterior vascular territories [43]. Most cases are asymptomatic, however, subsequent clinical and radiologic worsening is likely to occur [40-43]. In children, the clinical debut often implies ischemic events, such as transient ischemic attacks and ischemic infarcts, as well as focal seizures with headache, and intracranial hemorrhage might also be associated [40-43]. When symptoms are present, they include neurological findings such as paresthesia, headache, epileptic seizures, hemianopsia, nystagmus, aphasia, dysphasia and borderline mental level [16,40-43]. There are several lines of evidence indicating that moyamoya syndrome is related to genetic factors in familial cases. The gene abnormality has been detected in chromosome 17q25.2 [44]. NF1 gene is also mapped on chromosome 17q11.2 [2]. Hence, association of NF1 and moyamoya syndrome could be justified by close proximity neighboring of the responsible genes on chromosome 17 [10]. Moyamoya syndrome in NF1 patients is unilateral in up to $30 \%$ of cases, but the observation that progression to bilateral disease occurs in $10 \%-$ $100 \%$ of these patients means that our patient may require long-term surveillance, and noninvasive perfusion studies may be helpful for assessment $[9,45]$.

The diagnosis of moyamoya syndrome based on neuroimaging control. In patients with moyamoya syndrome, the brain computed tomography (CT) scan frequently shows ischemic and hemorrhagic lesions, although MRI is more helpful in the diagnosis of moyamoya syndrome because the provide greater parenchymal detail [46]. MRA is very useful for diagnosing moyamoya syndrome, with previous studies showing a sensitivity of $73 \%$ and a specificity of $100 \%$. Sensitivity increases to $92 \%$ when MRA is combined with MRI findings [46]. The diagnosis of moyamoya syndrome in our patient was supported with MRI and MRA, which is standard practice in our clinical routine screening of children with NF1.

Most patients with NF-1 associated with vascular lesions are asymptomatic. Early diagnosis and appropriate surgical management are of utmost importance, to improve cerebral hemodynamics and reduce the incidence of subsequent 
Table 1 Moyamoya syndrome in NF1 paediatric patients since 1976

\begin{tabular}{|c|c|c|c|c|c|}
\hline Authors & Year & Study & $\mathrm{N}$ (patients) & Age & $\begin{array}{c}\text { Patients with } \\
\text { moyamoya-NF1 }\end{array}$ \\
\hline Duat-Rodríguez A et al. [42] & 2014 & Retrospective review & 168 & & 4 \\
\hline Partha S. G et al. [40] & 2013 & Retrospective review & 312 & & 7 \\
\hline Kaas B et al. [43] & 2013 & Retrospective review & 187 & & 5 \\
\hline Ghosh, P. S., et al. [10] & 2012 & & 398 & & $15 / 312(4,8 \%)$ \\
\hline Luiz G D et al. [41] & 2011 & Case report & 1 & 8 months & 1 \\
\hline Ullrich, N. J. [11] & 2011 & Case report & & & 1 \\
\hline Smith, M [12] & 2011 & Case report & & $18 \mathrm{~m}$ boy & 1 \\
\hline Lin, N., et al. [13] & 2011 & Retrospective review 1988-2010 & 418 & $9.1 y(1-21 y)$ & 13 \\
\hline Horiguchi, S., et al. [14] & 2011 & Case report & 1 & $32 y$ & 1 \\
\hline Darrigo Junior, et al. [15] & 2011 & Case report & & $8 \mathrm{~m}$ female & 1 \\
\hline King, J. A., et al. [16] & 2010 & $\begin{array}{l}\text { Retrospective review } \\
\text { (May 1996-December 2008) }\end{array}$ & 33 & $<16 y$ & 3 \\
\hline Tan, R. M., S. M. Chng, et al. [17] & 2008 & Case report & 1 & $7 y$ female & 1 \\
\hline Koc, F., et al. [18] & 2008 & Case report & 1 & 20y female & 1 \\
\hline Borhani-Haghighi, A. and B. Sabayan [19] & 2008 & & & & \\
\hline Wintermark, P., et al. [20] & 2007 & Case report & & & 1 \\
\hline Ullrich, N. J., et al. [21] & 2007 & & & & \\
\hline Pascual-Castroviejo, l., et al. [22] & 2006 & & 12 & & 1 \\
\hline Desai, S. S., et al. [23] & 2006 & Review 1967-2002 & 54 & & 14 \\
\hline Fujimura, T., et al. [24] & 2004 & Case report & & 15y female & \\
\hline Scott, R. M., J. L. Smith, et al. [41] & 2004 & Retrospective review & 143 & $<20 y$ & 13 \\
\hline Hug, E. B., et al.[25] & 2002 & Retrospective review Sep 1991-Aug 1997 & 27 & & 1 \\
\hline El-Koussy, M., et al. [26] & 2002 & Case report & & & 1 \\
\hline Rodriguez-Jadraque, R., et al. [27] & 2000 & Case report & & $9 y$ & 1 \\
\hline Serdaroglu, A., et al. [20] & 2000 & Case report & & 4y female & 1 \\
\hline Piovesan, E. J., et al. [28] & 1999 & Case report & & $51 y$ & 1 \\
\hline Fujimoto, K., et al. [29] & 1999 & Case report & & 49y female & 1 \\
\hline Siqueira Neto, J. I., et al. [30] & 1998 & Case report & & 28y male & 1 \\
\hline Hattori, S., et al. [31] & 1998 & Case report & & $58 y$ female & 1 \\
\hline Barrall, J. et al. [32] & 1996 & Case report & & $19 \mathrm{~m}$ male & 1 \\
\hline Gorrotxategi, P., et al. [33] & 1994 & Case report & & 4y male & 1 \\
\hline Kestle, J. R., et al. [34] & 1994 & Retrospective review 1971-1990 & 47 & & 3 \\
\hline Woody, R. C., et al. [35] & 1992 & Case report & 1 & $3 \mathrm{~m}$ male & 1 \\
\hline Sobata, E., H. Ohkuma, et al. [36] & 1988 & Case report & 1 & 28y female & 1 \\
\hline Gracia, C. M., et al. [37] & 1986 & Case report & 1 & 33y female & 1 \\
\hline Quest, D. O. et al. [38] & 1985 & Retrospective review & 17 & & 1 \\
\hline \multirow[t]{2}{*}{ Sasaki, O., et al. [39] } & 1984 & Case report & 2 & 38y male & 2 \\
\hline & & & & 29y female & \\
\hline
\end{tabular}

ischemic events. However, close monitoring of these abnormalities is warranted because the long-term outcome of these vascular lesions is unknown. Moreover, early recognition of a cerebral vasculopathy may have helped prevent complications in several of these children $[8,47,48]$.
Surgical intervention has become the treatment of choice for patients with MMS, and particularly surgical revascularization in order to increase the blood flow to the hypoperfused cortex [49-51]. On the index patient, the surgical procedure of choice was EDAS (encephaloduroarteriosynangiosis) and resulted in no further symptoms or brain insults. 
In conclusion, vasculopathy in NF1 is a potentially serious and underestimated manifestation. MRA screening could be helpful in identified early vascular lesions in asymptomatic NF1 patients. Further studies are needed, in large cohorts of NF1 patients, to better understand the association between these conditions.

\section{Consent}

Written informed consent was obtained from the patient's guardian/parent/next of kin for the publication of this report and any accompanying images.

\section{Competing interests}

The authors declare that they have no competing interests.

\section{Authors' contribution}

EV acquiered, analysed and interpreted the data and drafted the biggest part of the manuscript. ES: acquired the data and drafted a small part of the manuscript. DS: acquired the data. SB: acquiered the data and critically revised the manuscript. MK: acquired the data. AA: performed and interpreted the neuroradiological studies and critically revised the manuscript. DIZ: critically revised the manuscript for important intellectual content and supervised the study. All authors read and approved the final manuscript.

\section{Author details}

${ }^{1} 1$ st Department of Pediatrics, Aristotle University of Thessaloniki, Egnatia St. 106, Thessaloniki 54622, Greece. Department of Radiology, "Hippokratio" General Hospital, Thessaloniki, Greece.

Received: 29 January 2014 Accepted: 13 April 2014

Published: 21 June 2014

\section{References}

1. Gutmann DH, Aylsworth A, Carey JC, Korf B, Marks J, Pyeritz RE, Rubenstein A, Viskochil D: The diagnostic evaluation and multidisciplinary management of neurofibromatosis 1 and neurofibromatosis 2. JAMA 1997, 27:851-857.

2. Friedman JM, Arbiser J, Epstein JA: Cardiovasscular disease in neurofibromatosis 1: report of the NF1 Cardiovascular Task Force. Genet Med 2002, 4:105-111.

3. NIH Consensus Development Program: Neurofibromatosis: National Institutes of Health Consensus Development Conference Statement. 1987, 6:1-19. Available from: http://consensus.nih.gov/1987/ 1987Neurofibramatosis064html.htm. Accessed in 2010 (Apr 19).

4. Sobata E, Ohkuma H, Suzuki S: Cerebrovascular disorders associated with von Recklinghausen's neurofibromatosis: a case report. Neurosurgery 1988, 22:544-549.

5. Yamada I, Himeno Y, Matsushima Y, Shibuya H: Renal artery lesions in patients with moyamoya disease: angiographic findings. Stroke 2000, 31:733-737.

6. Hamilton SJ, Friedman JM: Insights into the pathogenesis of neurofibromatosis 1 vasculopathy. Clin. Genet. 2000, 58:341-344.

7. Fukui M: Guidelines for the diagnosis and treatment of spontaneous occlusion of the circle of Willis ('moyamoya' disease). Research Committee on Spontaneous Occlusion of the Circle of Willis (Moyamoya Disease) of the Ministry of Health and Welfare, Japan. Clin Neurol Neurosurg 1997, 99:S238-S240.

8. Koss M, Scott RM, Irons MB, Smith ER, Ullrich NJ: Moyamoya syndrome associated with neurofibromatosis Type 1: perioperative and long-term outcome after surgical revascularization. J Neurosurg Pediatr 2013, 11:417-425.

9. Rosser TL, Vezina G, Packer RJ: Cerebrovascular abnormalities in a population of children with neurofibromatosis type 1. Neurology 2005 64:553-555

10. Bekiesińska-Figatowska M, Brągoszewska H, Duczkowski M, RomaniukDoroszewska A, Szkudlińska-Pawlak S, Duczkowska A, Mądzik J, Kowalska B,
Pęczkowski P: Circle of Willis abnormalities in children with neurofibromatosis type 1. Neurol Neurochir Pol 2014, 48(1):15-20.

11. Ullrich NJ, Zimmerman M, Smith E, Irons M, Marcus K, Kieran MW: Association of rapidly progressive moyamoya syndrome with bevacizumab treatment for glioblastoma in a child with neurofibromatosis type 1. J Child Neurol 2011, 26:228-30.

12. Smith M, Heran MK, Connolly MB, Heran HK, Friedman JM, Jett K, Lyons CJ Steinbok P, Armstrong L: Cerebrovasculopathy in NF1 associated with ocular and scalp defects. Am J Med Genet A 2011, 155A:380-5.

13. Lin N, Baird L, Koss M, Kopecky KE, Gone E, Ullrich NJ, Scott RM, Smith ER: Discovery of asymptomatic moyamoya arteriopathy in pediatric syndromic populations: radiographic and clinical progression. Neurosurg Focus 2011, 31:E6.

14. Horiguchi S, Mitsuya K, Watanabe R, Yagishita S, Nakasu Y: Pleomorphic xanthoastrocytoma and moyamoya disease in a patient with neurofibromatosis type 1 - case report. Neurol Med Chir (Tokyo) 2011, 51:310-4.

15. Darrigo Junior LG, Valera ET, Machado Ade A, Santos AC, Scrideli CA, Tone LG: Moyamoya syndrome associated with neurofibromatosis type I in a pediatric patient. Sao Paulo Med J 2011, 129:110-2.

16. King JA, Armstrong D, Vachhrajani S, Dirks PB: Relative contributions of the middle meningeal artery and superficial temporal artery in revascularization surgery for moyamoya syndrome in children: the results of superselective angiography. J Neurosurg Pediatr 2010, 5:184-9.

17. Tan RM, Chng SM, Seow WT, Wong J, Lim CC: 'Moya' than meets the eye: neurofibromatosis type 1 associated with Moyamoya syndrome. Singapore Med J 2008, 49:e107-9.

18. Koc F, Yerdelen D, Koc Z: Neurofibromatosis type 1 association with moyamoya disease. Int J Neurosci 2008, 118:1157-63.

19. Borhani-Haghighi A, Sabayan B: Photoclinic: moyamoya disease associated with neurofibromatosis 1. Arch Iran Med 2008, 11:473-4.

20. Wintermark P, Meagher-Villemure K, Villemure JG, Maeder-Ingvar M, Maeder $P$, Ghariani S, Roulet-Perez E: Progressive unilateral hemispheric atrophy in an infant with neurofibromatosis. Neuropediatrics 2007, 38:100-4.

21. Ullrich NJ, Robertson R, Kinnamon DD, Scott RM, Kieran MW, Turner CD, Chi SN, Goumnerova L, Proctor M, Tarbell NJ, Marcus KJ, Pomeroy SL: Moyamoya following cranial irradiation for primary brain tumors in children. Neurology 2007, 68:932-8.

22. Pascual-Castroviejo I, Pascual-Pascual SI, Velázquez R, Viano J, Martinez V: Moyamoya disease: follow-up of 12 patients. Neurologia 2006, 21:695-703.

23. Desai SS, Paulino AC, Mai WY, The BS: Radiation-induced moyamoya syndrome. Int J Radiat Oncol Biol Phys 2006, 65:1222-7.

24. Fujimura T, Terui T, Kusaka Y, Tagami H: Neurofibromatosis 1 associated with an intracranial artery abnormality, moyamoya disease and bilateral congenital large hairy pigmented macules. Br J Dermatol 2004, 150:611-3.

25. Hug EB, Muenter MW, Archambeau JO, DeVries A, Liwnicz B, Loredo LN, Grove RI, Slater JD: Conformal proton radiation therapy for pediatric low-grade astrocytomas. Strahlenther Onkol 2002, 178:10-7.

26. El-Koussy M, Lövblad KO, Steinlin M, Kiefer C, Schroth G: Perfusion MRI abnormalities in the absence of diffusion changes in a case of moyamoya-like syndrome in neurofibromatosis type 1. Neuroradiology 2002, 44:938-41.

27. Rodriguez-Jadraque R, Martinez-Salio A, de Alvaro MT G, Porta-Etessam J, Torres-Mohedas J, Mateos-Beato F: Arteriovenous malformation in neurofibromatosis type 1 . A case report and review of the literature. Rev Neurol 2000, 31:1043-5.

28. Serdaroglu A, Simsek F, Gücüyener K, Oǧuz A, Karadeniz C, Balibey M: Moyamoya syndrome after radiation therapy for optic pathway glioma: case report. J Child Neurol 2000, 15:765-7

29. Piovesan EJ, Scola RH, Werneck LC, Zetola VH, Novak EM, Iwamoto FM, Piovesan LM: Neurofibromatosis, stroke and basilar impression: Case report. Arq Neuropsiquiatr 1999, 57:484-8.

30. Fujimoto K, Shimomura T, Okumura Y: Severe stenosis of the internal carotid artery and intracerebral hematoma associated with neurofibromatosis type 1: a case report. No Shinkei Geka 1999, 27:61-5.

31. Siqueira Neto Jl, Silva GS, De Castro JD, Santos AC: Neurofibromatosis associated with moyamoya arteriopathy and fusiform aneurysm: case report. Arq Neuropsiquiatr 1998, 56:819-23.

32. Hattori S, Kiguchi H, Ishii T, Nakajima T, Yatsuzuka H: Moyamoya disease with concurrent von Recklinghausen's disease and cerebral arteriovenous malformation. Pathol Res Pract 1998, 194:363-9. 
33. Barrall JL, Summers CG: Ocular ischemic syndrome in a child with moyamoya disease and neurofibromatosis. Surv Ophthalmol 1996, 40:500-4.

34. Gorrotxategi P, Reguilon MJ, Gaztanaga R, Hernandez Abenza J, Albisu Y: Moya-moya disease in a child with multiple malformations. Rev Neurol 1995, 23:403-5.

35. Kestle JR, Hoffman HJ, Mock AR: Moyamoya phenomenon after radiation for optic glioma. J Neurosurg 1993, 79:32-5.

36. Woody RC, Perrot LJ, Beck SA: Neurofibromatosis cerebral vasculopathy in an infant: clinical, neuroradiographic, and neuropathologic studies. Pediatr Pathol 1992, 12:613-9.

37. Gracia CM, Bittencourt PC, Mazer S, Bittencourt PR: Neurofibromatosis and extensive intracranial arterial occlusive disease (moyamoya disease). Report of a case]. Arq Neuropsiquiatr 1986, 44:395-400.

38. Quest DO, Correll JW: Basal arterial occlusive disease. Neurosurgery 1985, 17:937-41.

39. Sasaki O, Ishii R, Koike T, Tanaka R: Multiple cerebrovascular occlusive disease associated with neurofibromatosis. No To Shinkei 1984, 36:159-66.

40. Ghosh PS, David Rothner A, Emch TM, Neil R, Friedman and Manikum Moodley: Cerebral Vasculopathy in Children with Neurofibromatosis Type 1. J Child Neurol 2013, 28:95-101.

41. Luiz GD, Valera Terci E, De Aboim MA, Dos Santos CA, Scrideli CA, Gonzaga Tone L: Moyamoya syndrome associated with neurofibromatosis type I in a pediatric patient. Sao Paulo Med J 2011, 129(2):110-2.

42. Duat-Rodríguez A, Carceller Lechón F, Angel Lopez Pino M, Rodriguez Fernandez C, González-Gutiérrez-Solana L: Neurofibromatosis Type 1 Associated With Moyamoya Syndrome in Children. Pediatric Neurology 2014, 50:96-98.

43. Kaas B, Thierry A, Huisman GM, Tekes A, Bergner A, Blakeley JO, Jordan LC: Spectrum and Prevalence of Vasculopathy in Pediatric Neurofibromatosis Type 1.J Child Neurol 2013, 28:561-569.

44. Yamauchi T, Tada M, Houkin K, Tanaka T, Nakamura Y, Kuroda S, Abe H, Inoue T, Ikezaki K, Matsushima T, Fukui M: Linkage of familial moyamoya disease (spontaneous occlusion of the circle of Willis) to chromosome 17q25. Stroke 2000, 31:930-935

45. Seol HJ, Wang KC, Kim SK, Lee CS, Lee DS, Kim IO, Cho BK: Unilateral (probable) moyamoya disease: long-term follow-up of seven cases. Childs Nerv Syst 2006, 22:145-50.

46. Katz DA, Marks MP, Napel SA, Bracci PM, Roberts SL: Circle of Willis: evaluation with spiral $\mathrm{CT}$, angiography, MRA and conventional angiography. Radiology 1995, 195:445-449.

47. Gorelik MH, Powell CM, Rosenbaum KN, Saal HM, Conry J, Fitz CR Progressive occlusive cerebrovascular disease in a patient with neurofibromatosis type 1. Clin Pediatr 1992, 31:3153-315.

48. Scott RM: Moyamoya syndrome: a surgically treatable cause of stroke in the pediatric patient. Clin Neurosurg 2000, 47:378-384

49. Veeravagu A, Guzman R, Path CG: Moyamoya disease in pediatric patients: outcomes of neurosurgical interventions Neurosurg. Focus 2008, 24:1-9.

50. Scott RM, Smith JL, Robertson RL, Madsen JR, Soriano SG, Rockoff MA: Long-term outcome in children with moyamoya syndrome after cranial revascularization by pial synangiosis. J Neurosurg 2004, 100:142-149.

51. Fung LW, Thompson D, Ganesan V: Revascularisation surgery for paediatric moyamoya: a review of the literature. Childs Nerv Syst 2005, 21:358-364.

\section{Submit your next manuscript to BioMed Central and take full advantage of:}

- Convenient online submission

- Thorough peer review

- No space constraints or color figure charges

- Immediate publication on acceptance

- Inclusion in PubMed, CAS, Scopus and Google Scholar

- Research which is freely available for redistribution

Submit your manuscript at www.biomedcentral.com/submit
C Biomed Central 